\title{
Self-Cementitious Hydration of Circulating Fluidized Bed Combustion Fly Ash
}

\author{
Seung-Heun Lee ${ }^{\dagger}$ and Guen-Su Kim \\ Department of Materials Science and Engineering, Kunsan National University, Gunsan 54150, Korea \\ (Received October 26, 2016; Revised February 15, 2017; Accepted February 22, 2017)
}

\begin{abstract}
Fly ash from a circulating fluidized bed combustion boiler (CFBC fly ash) is very different in mineralogical composition, chemical composition, and morphology from coal ash from traditional pulverized fuel firing because of many differences in their combustion processes. The main minerals of CFBC fly ash are lime and anhydrous gypsum; however, due to the fuel type, the strength development of CFBC fly ash is affected by minor components of active $\mathrm{SiO}_{2}$ and $\mathrm{Al}_{2} \mathrm{O}_{3}$. The initial hydration product of the circulating fluidized bed combustion fly ash (B CFBC ash) using petro coke as a fuel is Portlandite which becomes gypsum after 7 days. Due to the structural features of the portlandite and gypsum, the self-cementitious strength of B CFBC ash was low. While the hydration products of the circulating fluidized bed combustion fly ash (A CFBC ash) using bituminous coal as a fuel were initially portlandite and ettringite, after 7 days the hydration products were gypsum and C-S-H. Due to the structural features of ettringite and C-S-H, A CFBC ash showed a certain degree of self-cementitious strength.
\end{abstract}

Key words : CFBC fly ash, Hydration products, Self-cementitous strength, Fuel type

\section{Introduction}

C irculating fluidized bed combustion (CFBC) boilers are known to be appropriate for effective combustion of low quality coals, such as high sulfur content coals. ${ }^{1-3)}$ Recently, considering the coal supply conditions in Korea, CFBC boiler-based heat power plants have been actively introduced, and the coal ash discharged from the CFBC boilers is expected to reach about one million tons in 2017. The most important feature of CFBS boilers is that the $\mathrm{SO}_{2}$ (gas) component produced by the combustion of fuels, such as coals, is removed as $\mathrm{CaSO}_{4}$ (solid) through a reaction with limestone put into the boilers. Since the general limestone input is at a $\mathrm{Ca} / \mathrm{S}$ molar ratio of 2 to 2.5 , the fly ash discharged from CFBC boilers (CFBC fly ash) includes unreacted lime (f$\mathrm{CaO})$ and anhydrous gypsum $\left(\mathrm{CaSO}_{4}\right)^{2)}$ In addition, in comparison to the temperature of traditional pulverized combustion $(\mathrm{PC})\left(1,300\right.$ to $\left.1,500^{\circ} \mathrm{C}\right)$, the combustion temperature of $\mathrm{CFBC}$ boilers is relatively low at 850 to $900^{\circ} \mathrm{C}$. ${ }^{3)}$ In contrast to the fly ash exhausted from PC boilers, the particles of CFBC fly ash are amorphous due to the low combustion temperature, and contain less $\mathrm{SiO}_{2}$, which contributes to the Pozzolanic reaction, because no glass phase is formed. . $^{4-6)}$

The self-cementitious property refers to the property of being solidified and hardened by the addition of water, as in the case of ordinary Portland cement (OPC). Freidin et al. reported that $\mathrm{CFBC}$ fly ash containing more quicklime (f-

\footnotetext{
${ }^{\dagger}$ Corresponding author: Seung-Heun Lee

E-mail : shlee@kunsan.ac.kr

Tel : +82-63-469-4731 Fax : +82-63-462-6982
}

$\mathrm{CaO}$ ) and $\mathrm{SO}_{3}$ showed a higher self-cementitious property and higher compressive strength. The strength was dependent on the curing method, and air-drying curing showed extremely low strength. ${ }^{7)}$ Sheng et al. reported that the selfcementitious property of CFBC fly ash was dependent on the fineness and the chemical composition, and that higher strength was shown due to the self-cementitious property in CFBC fly ash containing more $\mathrm{f}-\mathrm{CaO}$ and $\mathrm{SO}_{3}{ }^{3}{ }^{3}$ Sheng et al. also investigated the effect that the $\mathrm{f}-\mathrm{CaO}$ contained in CFBC fly ash has on the self-cementitious property and reported that the slacking of CFBC fly ash has the greatest effect on the self-cementitious property and facilitates setting. They explained that the mechanism of the self-cementitious property may involve generation of $\mathrm{Ca}(\mathrm{OH})_{2}$ micelles by the slacking of $\mathrm{f}-\mathrm{CaO}$, generation of ettringite by $\mathrm{CaSO}_{4}$, $\mathrm{Ca}(\mathrm{OH})_{2}$, and reactive $\mathrm{Al}_{2} \mathrm{O}_{3}$, and generation of C-S-H by $\mathrm{Ca}(\mathrm{OH})_{2}$ and reactive $\mathrm{SiO}_{2}{ }^{8}$ )

In the present study, the self-cementitious property of CFBC fly ash discharged in Korea by using bituminous coal and petro coke as fuels was investigated in order to utilize the fly ash discharged from CFBC boilers as a construction materials.

\section{Experimental Procedure}

\subsection{Materials}

The present study was conducted using CFBC fly ash produced from a CFBC boiler using bituminous coal as fuel (A CFBC ash) and CFBC fly ash produced from the CFCB boiler using petro coke as fuel (B CFBC ash). The sulfide content levels in the bituminous coal and the petro coke 
Table 1. Physical Properties of CFBC Ash

\begin{tabular}{lccc}
\hline & $\begin{array}{c}\text { Density } \\
\left(\mathrm{g} / \mathrm{cm}^{3}\right)\end{array}$ & $\begin{array}{c}\text { Blaine } \\
\left(\mathrm{cm}^{2} / \mathrm{g}\right)\end{array}$ & $\begin{array}{c}\text { Average Particle Size } \\
(\mu \mathrm{m})\end{array}$ \\
\hline A CFBC Ash & 3.03 & 2,400 & 20.0 \\
B CFBC Ash & 3.00 & 2,700 & 12.4 \\
\hline
\end{tabular}

Table 2. Chemical Composition of CFBC Ash

\begin{tabular}{lccccccc}
\hline & \multicolumn{7}{c}{ Chemical Composition (\%) } \\
\cline { 2 - 8 } & $\mathrm{SiO}_{2}$ & $\mathrm{CaO}$ & $\mathrm{Al}_{2} \mathrm{O}_{3}$ & $\mathrm{Fe}_{2} \mathrm{O}_{3}$ & $\mathrm{MgO}$ & $\mathrm{SO}_{3}$ & f-CaO \\
\hline A CFBC Ash & 12.1 & 64.3 & 5.8 & 3.4 & 2.9 & 5.2 & 27.6 \\
B CFBC Ash & 1.8 & 70.1 & 0.5 & 0.3 & 0.9 & 22.0 & 18.6 \\
\hline
\end{tabular}

were $0.5 \%$ and $6.7 \%$, respectively, and the ash content values were $10.5 \%$ and $0.7 \%$, respectively. Hence, the types of CFCB fly ash discharged from the two kinds of fuel had significant differences in chemical composition. Table 1 shows the physical properties of the fly ashes used in the experiment. Table 2 shows the fly ash chemical composition measured using X-ray fluorescence (XRF, Rigaku Co., ZSX Primus II). To assess the reactivity of the lime and anhydrous gypsum contained in the CFBC fly ash, the hydration reactivity of a mixture prepared by mixing reagent-grade quicklime (SAMCHUN Co.) 59.3\% and natural anhydrous gypsum from Thailand 40.7\% (P1, Blaine specific area 3,000 $\mathrm{cm}^{2} / \mathrm{g}$ ) was compared and assessed with reference to the chemical composition of $\mathrm{B}$ CFBC ash. The mixing ratios were determined by referring to the chemical composition of $\mathrm{B}$ CFBC ash and assuming that all the $\mathrm{SO}_{3}$ is included in the anhydrous gypsum. The OPC used in this experiment was a commercially available Portland cement (S Company).

\subsection{Experimental}

To investigate the hydration reactivity, the mixing ratio of CFBC fly ash to water was set at 1.0, and the sample, after kneading, was injected into a sealed container to hydrate in a thermohygrostat at $20 \pm 1^{\circ} \mathrm{C}$ and $90 \%$ relative humidity until a material age of day 91 . After a certain period of time, the sample was pulverized into particles having a diameter of $5 \mathrm{~mm}$ or smaller, and deposited in acetone for $12 \mathrm{~h}$ to stop the hydration. After stopping the hydration, the sample was dried at $40^{\circ} \mathrm{C}$ for $24 \mathrm{~h}$ and then stored in a vacuum desiccator.

The resulting hydrate was analyzed using XRD (Panalytical Co., EMPY REAN). The reaction ratio between lime and anhydrous gypsum, depending on the hydration time, was calculated using a semi-quantitative method by comparing the X-ray diffraction intensity of the peak of lime measured at $2 \theta=37.3^{\circ}$ and that of anhydrous gypsum measured at $2 \theta=25.4^{\circ}$. The reaction ratio was calculated by correcting the bound water with the loss on ignition, as shown in Equation (1). The loss on ignition was obtained by calculating the loss after three hours of sample treatment at $1000^{\circ} \mathrm{C}$.

$$
R=100-\left[\frac{I(100-L O I(t))}{I_{0}\left(100-L O I\left(t_{0}\right)\right)}\right] \times 100
$$

In Equation (1), $\mathrm{R}$ denotes the reaction ratio (\%), I the XRD peak area at time $t, I_{0}$ the XRD peak area before hydration, LOI $(\mathrm{t})$ the loss on ignition at time $t$, and LOI $\left(\mathrm{t}_{0}\right)$ the loss on ignition before hydration.

The microstructure of the hydrate was analyzed using a field emission scanning electron microscope (FE-SEM, S4800, HITACHI) equipped with an energy dispersive spectrum (EDS, HORI-BA, EX-250). The initial hydration reaction was evaluated by measuring the temperature. The temperature measurement was performed using a static data logger (UCAM-60B) for three days. The thermal analysis was performed using thermogravimetry differential scanning calorimetry (TG-DSC, TA Instruments Ltd., SDT Q600) to verify the presence of C-S-H. The thermal analysis was performed in an $\mathrm{Ar}$ atmosphere at a rate of $5^{\circ} \mathrm{C} / \mathrm{min}$. Chemical analysis of active $\mathrm{SiO}_{2}$, which is the type of CFBC fly ash that may form C-S-H, was performed by following the EN 196-2 method. ${ }^{9)}$ In addition, chemical analysis of active $\mathrm{Al}_{2} \mathrm{O}_{3}$, which may form ettringite, was performed by the method described by Sheng et al. ${ }^{3)}$

When CFBC fly ash is mixed with water, preparation of compressive strength specimens becomes difficult due to the high hydration heat. In the present experiment, to control the initial heat generation, $\mathrm{f}-\mathrm{CaO}$ content was measured by the ethylene glycol method of KS L 5405, and half of the water theoretically required to convert $\mathrm{f}-\mathrm{CaO}$ to $\mathrm{Ca}(\mathrm{OH})_{2}$ was provided and mixed. Then, to prepare the compressive strength specimens, the rest of the water was mixed in 10 minutes after the maximum heat generation time. The total water quantity was determined with reference to the waterbinder ratio of 0.5 . The specimens were prepared with sizes of $5 \mathrm{X} 5 \mathrm{X} 5 \mathrm{~cm}$, and were cured at $20 \pm 1^{\circ} \mathrm{C}$ and $90 \%$ or higher relative humidity to measure the compressive strength of the paste.

\section{Results and Discussion}

\subsection{Mineral properties of CFBC fly ash}

Table 2 shows that the $\mathrm{SO}_{3}$ content in B CFBC ash was $22.0 \%$, which was about four times higher than that of $\mathrm{A}$ $\mathrm{CFBC}$ ash. The $\mathrm{CaO}$ content was also $6.2 \%$ higher in $\mathrm{B}$ CFBC ash. This was because, to remove sulfur, more limestone was added to B CFBC ash discharged from the boiler using petro coke, which includes more sulfur in the fuel. On the other hand, the f-CaO content was lower in B CFBC ash than in A CFBC ash because B CFBC ash included more $\mathrm{SO}_{3}$, which reacted with $\mathrm{CaO}$ to produce $\mathrm{CaSO}_{4}$

Figure 1 shows the results of the XRD identification of the minerals included in the CFBC fly ash. Regardless of the type of the fly ash, the major minerals were quicklime $(\mathrm{CaO})$ and anhydrous gypsum $\left(\mathrm{CaSO}_{4}\right)$; the minor minerals were a-quartz $\left(\mathrm{a}-\mathrm{SiO}_{2}\right)$ and calcite $\left(\mathrm{CaCO}_{3}\right)$. In contrast to conventional pulverized coal combustion boilers, CFBC boilers use limestone to perform desulfurization, and thus the major minerals contained in the CFBC fly ash are quicklime and anhydrous gypsum. The identified a-quartz was originally 


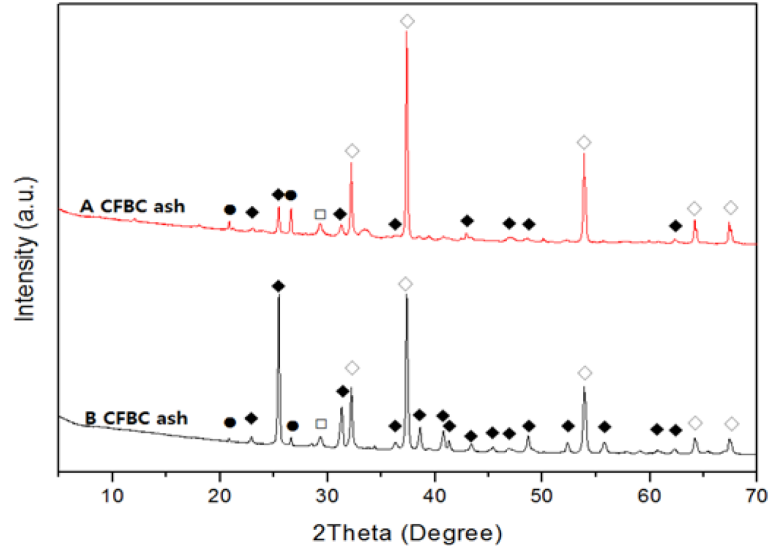

Fig. 1. XRD patterns of CFBC ash $(\bullet \alpha$-Quartz, $\bullet$ Anhydrous gypsum, $\diamond$ Lime, $\square$ Calcite).

contained in the coal, and the calcite was produced by the reaction between some of the lime and $\mathrm{CO}_{2}$ in the air. The minerals containing $\mathrm{Al}_{2} \mathrm{O}_{3}$, shown in Table 2 , were not identified by XRD, probably because the clay minerals included in the coal were calcinated into lowly crystalline substances that could not be identified by XRD analysis.

\subsection{Shape of CFBC fly ash particles}

Figure 2 provides SEM images of the particles of A CFBC ash and $\mathrm{B}$ CFBC ash. In contrast to the particles of pulverized coal fly ash, most of the particles of A CFBC ash and B CFBC ash were not spherical but had irregular shapes. According to the EDS analysis results shown in Table 3, most of A CFBC ash particles were particles consisting of $\mathrm{Ca}$ and $\mathrm{S}$ components found at Point 1; particles consisting of $\mathrm{Si}$ and $\mathrm{Al}$ components were found at Point 2. On the contrary, the components of B CFBC ash particles found at Points 1 and 2 were similar, and most of the particles consisted of $\mathrm{Ca}$ and $\mathrm{S}$ components. This shows that regardless of the fuel, the CFBC fly ashes commonly include a considerable amount of particles consisting of $\mathrm{Ca}$ and $\mathrm{S}$. The chemical compositions of the particles were $12.2 \%$ to $19.5 \%$ $\mathrm{Ca}$ and $4.1 \%$ to $8.6 \% \mathrm{~S}$, indicating that the particles, due to the high Ca content, can hardly be considered to be anhydrous gypsum particles. In the process in which anhydrous gypsum is produced in a CFBC boiler, the sulfur volatilized

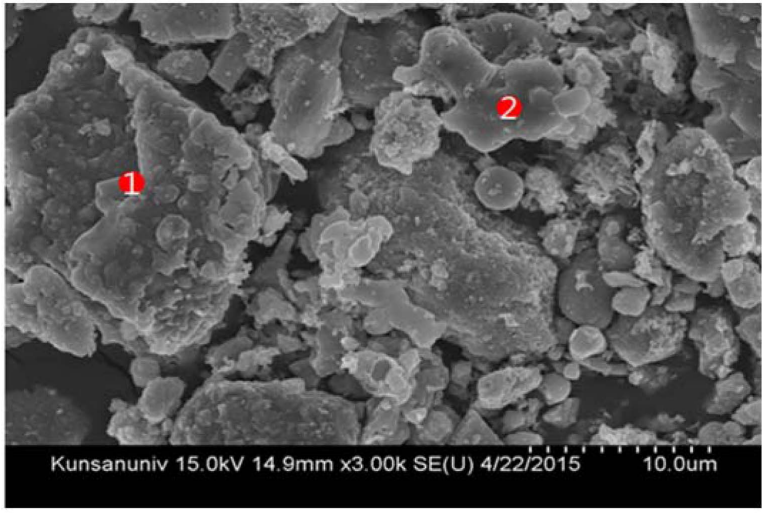

(a) A CFBC ash

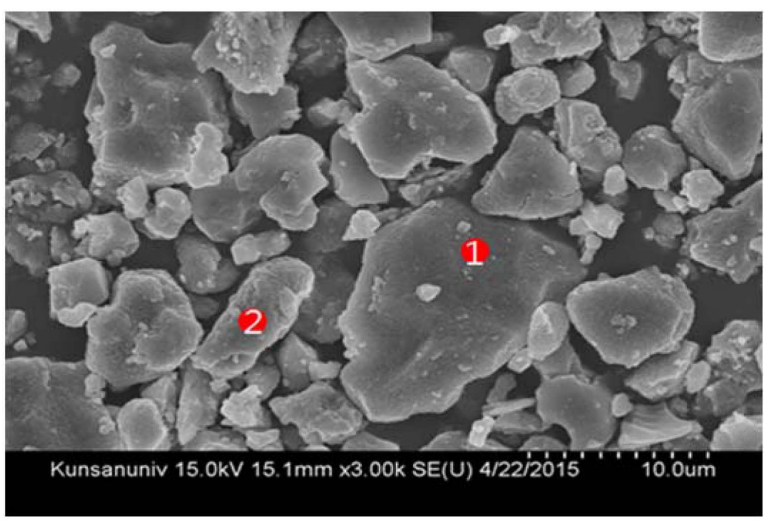

(b) B CFBC ash

Fig. 2. SEM Images of CFBC ash (a) A CFBC ash, (b) B CFBC ash.

Table 3. SEM-EDS Point Analysis of A, B CFBC Ash

\begin{tabular}{ccccc}
\hline & \multicolumn{4}{c}{ Element Analysis (\%) } \\
\cline { 2 - 5 } & A point 1 & A point 2 & B point 1 & B point 2 \\
\hline $\mathrm{Ca}$ & 19.8 & 0.4 & 19.0 & 12.2 \\
$\mathrm{O}$ & 65.0 & 74.4 & 76.5 & 78.6 \\
$\mathrm{~S}$ & 4.7 & - & 4.1 & 8.6 \\
$\mathrm{Si}$ & 0.2 & 8.8 & 0.4 & - \\
$\mathrm{Al}$ & - & 8.3 & - & - \\
e.t.c & 10.3 & 8.1 & - & 0.6 \\
\hline Total & 100 & 100 & 100 & 100 \\
\hline
\end{tabular}

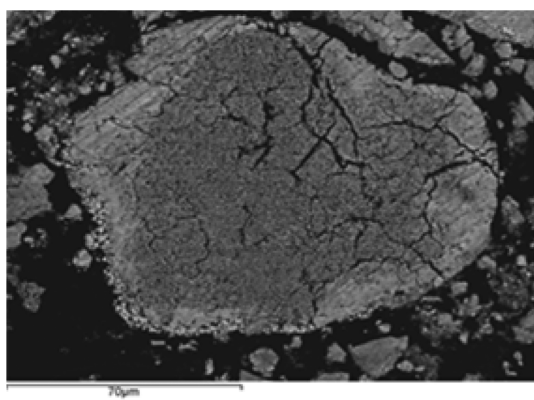

(a) Particle morphology

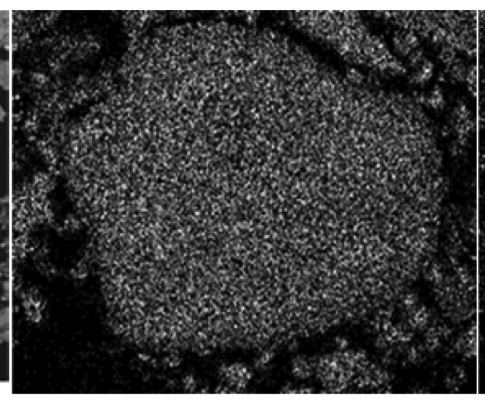

(b) Ca distribution

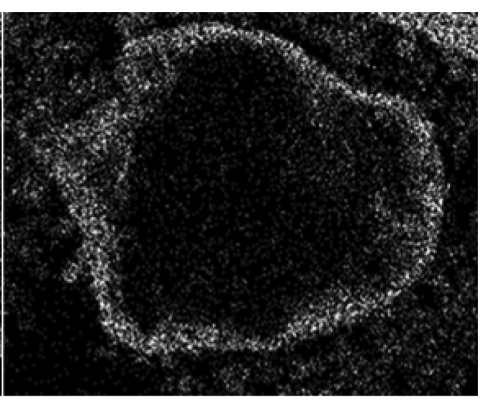

(c) $\mathrm{S}$ distribution

Fig. 3. SEM-EDS images of polished B CFBC ash particles (a) Particle morphology, (b) Ca distribution, (c) S distribution. 
from the fuel is oxidized into $\mathrm{SO}_{2}$ (g) and the limestone added to remove the sulfur is thermally decomposed in a temperature range of 850 to $900^{\circ} \mathrm{C}$. The surface of the lime particles reacts with $\mathrm{SO}_{2}(\mathrm{~g})$ and $\mathrm{O}_{2}(\mathrm{~g})$ to produce anhydrous gypsum, which wraps the quicklime particle surfaces. To verify the shape, the particles corresponding Point 1 of A CFBC ash were polished and analyzed by SEM-EDS. As shown in Fig. 3, the $\mathrm{S}$ components were concentrated on the particle surface, while the $\mathrm{Ca}$ and $\mathrm{O}$ components were uniformly distributed. Therefore, the inside of the particles was composed of quicklime, but the surface was wrapped by anhydrous gypsum. Such a coating hinders the hydration of quicklime, because water may not easily penetrate through the $\mathrm{CaSO}_{4}$ layer. However, since the $\mathrm{CaSO}_{4}$ layer is heterogeneous, as shown in Fig. 3, a thin $\mathrm{CaSO}_{4}$ layer may be dissolved by water within several tens of minutes, and uncoated parts may rapidly react with water.

\subsection{Initial hydration heat properties}

The initial hydration heat was evaluated by measuring the variation of the temperature during the reaction until day 3 of hydration. Fig. 4 shows the measured temperature variation. The data were shown in comparison with OPC. Both types of CFBC fly ash showed a drastic increase of the temperature, which reached $105^{\circ} \mathrm{C}, 30$ minutes after the initiation of the hydration. On the contrary, the temperature of OPC was $40^{\circ} \mathrm{C}$ about $17 \mathrm{~h}$ after the initiation of the hydration, indicating that the initial hydration heat of OPC was much lower than that of the CFBC fly ash. The initial rapid temperature increase results because quicklime has an exposed surface that reacts with water to produce portlandite $\left(\mathrm{Ca}(\mathrm{OH})_{2}\right)$, generating heat of $15.6 \mathrm{kcal} / \mathrm{mol}^{3}{ }^{3)} \mathrm{B} \mathrm{CFBC}$ ash, in spite of having $6.3 \%$ less $\mathrm{CaO}$ in comparison with the CFBC Ash, showed a similar maximum temperature, indicating that the amount of quicklime exposed to water was similar. A CFBC ash required about nine more hours to return to room temperature, which might have been because of the presence of a reaction to produce ettringite, in which reaction $\mathrm{Al}_{2} \mathrm{O}_{3}$ is involved. On the other hand, $\mathrm{B}$ CFBC ash returned to room temperature more rapidly

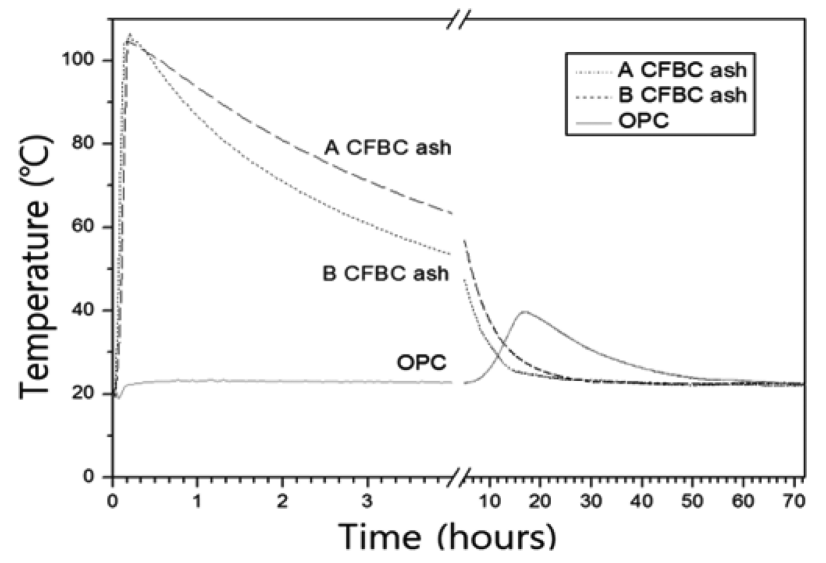

Fig. 4. Temperature rise of $\mathrm{A}, \mathrm{B} \mathrm{CFBC}$ ash. because $\mathrm{B}$ CFBC ash contained almost no $\mathrm{Al}_{2} \mathrm{O}_{3}$ and less f$\mathrm{CaO}$.

\subsection{Properties of hydrates}

Figure 5 shows the results of the mineral identification

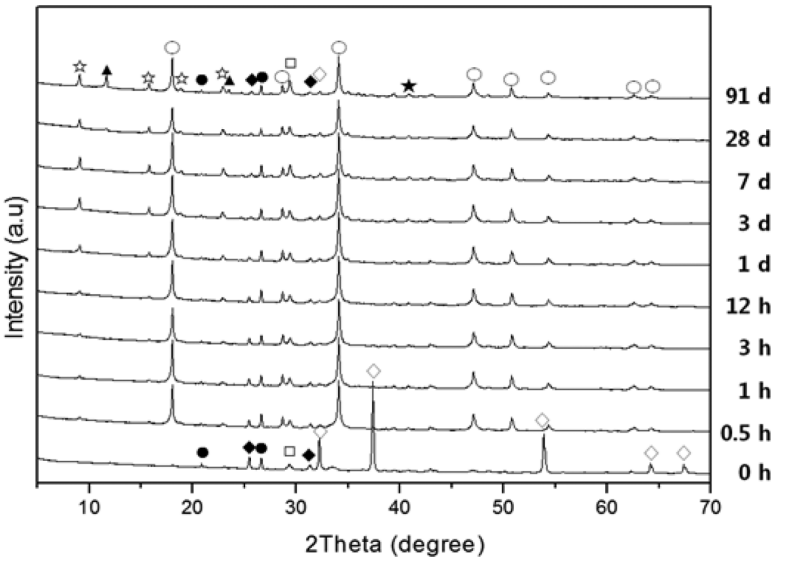

(a) A CFBC ash

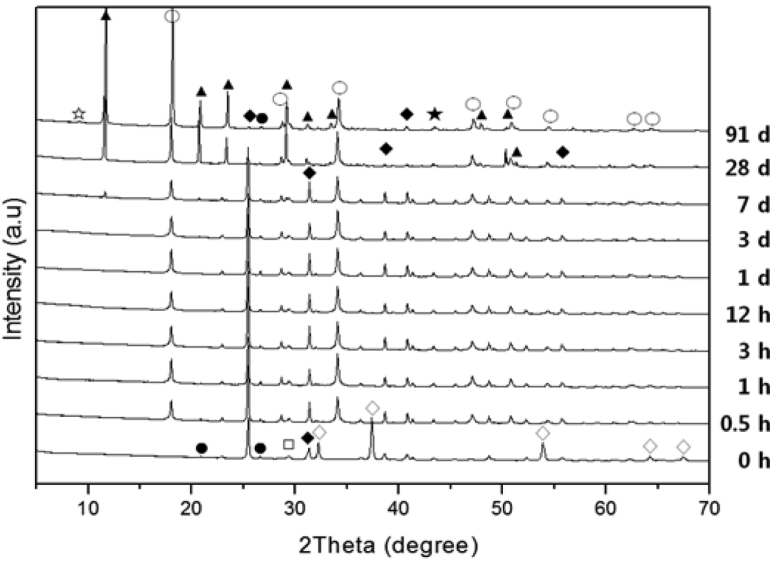

(b) B CFBC ash

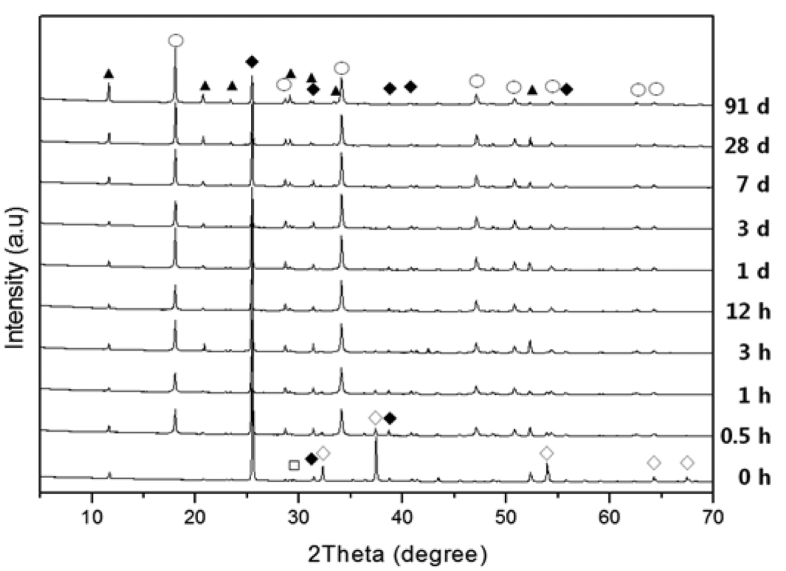

(c) P1

Fig. 5. XRD patterns of hydrated CFBC ash and $\mathrm{P} 1$ with curing time (ム Gypsum, $\bigcirc$ Portlandite, $\bullet \alpha$-Quartz, $\diamond$ Lime, $\diamond$ Anhydrous gypsum, $\square$ Calcite, is Ettringite, $\star$ Magnetite) (a) A CFBC ash, (b) B CFBC ash, (c) P1. 
Table 4. Amounts of Active $\mathrm{SiO}_{2}$ and $\mathrm{Al}_{2} \mathrm{O}_{3}$ Component

\begin{tabular}{cccccc}
\hline & \multicolumn{3}{c}{ Chemical Composition (\%) } \\
\cline { 2 - 3 } \cline { 5 - 6 } \cline { 5 - 6 } & \multicolumn{2}{c}{$\mathrm{SiO}_{2}$} & & \multicolumn{2}{c}{$\mathrm{Al}_{2} \mathrm{O}_{3}$} \\
\cline { 2 - 3 } \cline { 5 - 6 } A CFBC ash & Total & Active & & Total & Active \\
\hline B CFBC ash & 12.1 & 10.0 & & 5.8 & 2.8 \\
\hline
\end{tabular}

performed until day 91 of hydration to investigate the properties of the hydrates. Regardless of the type of the fly ash, the production of portlandite, a hydrate of quicklime, was completed within the initial 30 minutes, and thus the peak intensity hardly changed after that time. In the case of $\mathrm{P} 1$ the peak of portlandite increased on day 1 of hydration, but did not change thereafter. Hence, the activity of the quicklime contained in the CFBC fly ash was higher than that of the reagent-grade quicklime. This result is consistent with a report that the activity that $\mathrm{CaO}$ produces in a temperature range of 800 to $900^{\circ} \mathrm{C}$, the limestone degradation temperature, is very high. ${ }^{11,12)}$ With regard to the peak of ettringite $\left(3 \mathrm{CaO} \cdot \mathrm{Al}_{2} \mathrm{O}_{3} \cdot 3 \mathrm{CaSO}_{4} \cdot 32 \mathrm{H}_{2} \mathrm{O}\right)$, the ettringite peak in A CFBC ash appeared 30 minutes after the initiation of the hydration, and the peak intensity increased over time. No ettringite peak was found in the XRD data in the cases of B CFBC ash and $\mathrm{P} 1$ Production of ettringite requires an $\mathrm{Al}_{2} \mathrm{O}_{3}$ component for the reaction. Table 4 shows the measured active $\mathrm{Al}_{2} \mathrm{O}_{3}$ component and the active $\mathrm{SiO}_{2}$ component. An active component refers to an $\mathrm{Al}_{2} \mathrm{O}_{3}$ component and an $\mathrm{SiO}_{2}$ component that are eluted in strong alkaline atmosphere and that have the capacity to produce a hydrate. In A CFBC ash, the active $\mathrm{Al}_{2} \mathrm{O}_{3}$ component was present as $10.0 \%$ out of the total $\mathrm{Al}_{2} \mathrm{O}_{3}$ component (12.1\%). However, no active $\mathrm{Al}_{2} \mathrm{O}_{3}$ component was found in $\mathrm{B} \mathrm{CFBC}$ ash, and thus ettringite could hardly be produced. With regard to gypsum $\left(\mathrm{CaSO}_{4} \cdot 2 \mathrm{H}_{2} \mathrm{O}\right)$, which is a hydrate of anhydrous gypsum, a weak peak of gypsum was found on day 28 of hydration, and a full peak was found on day 91 in A CFBC ash. This means that the anhydrous gypsum that was not used to produce ettringite was converted to gypsum. In B CFBC ash, the peak of gypsum appeared on day 7 of hydration, and the peak became bigger as the period of hydration increased to day 28 and day 91. Therefore, if there is an active $\mathrm{Al}_{2} \mathrm{O}_{3}$ component in CFBC ash, anhydrous gypsum produces ettringite, and then the remaining anhydrous gypsum is gradually converted to gypsum. In the case of $\mathrm{P} 1$, a gypsum peak was found 30 minutes after the initiation of the hydration, and the peak size gradually increased over the hydration period. However, B CFBC ash showed a bigger peak from day 28 of hydration. This may be because the anhydrous gypsum contained in the CFBC ash was produced at a high temperature between 850 and $900^{\circ} \mathrm{C}$ and thus had a lower solubility than that of natural anhydrous gypsum.

Figures 6 and 7 show the reaction ratios of quicklime and anhydrous gypsum, depending on the hydration time, calculated using Equation (7). The reaction of the quicklime con-

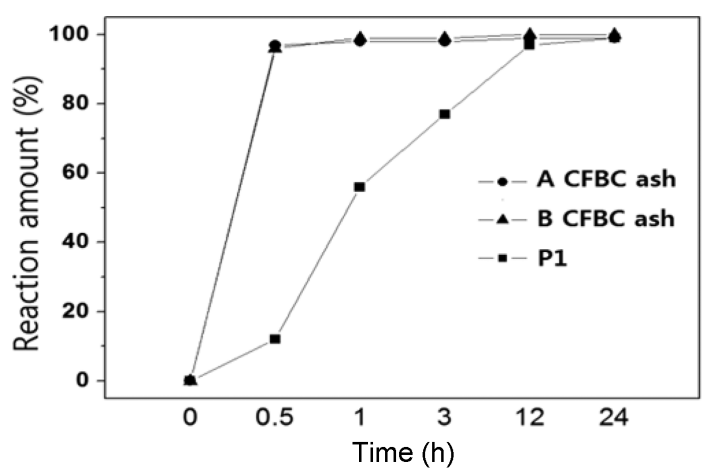

Fig. 6. $\mathrm{CaO}$ reaction amount of $\mathrm{A}, \mathrm{B} \mathrm{CFBC}$ ash and $\mathrm{P} 1$.

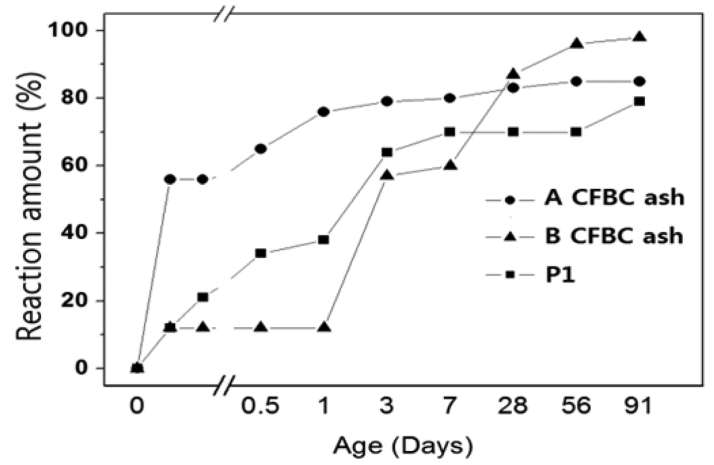

Fig. 7. Anhydrous gypsum reaction amount of A, B CFBC ash and P1.

tained in the CFBC ash was completed 30 minutes after the initiation of the hydration, but the reaction was completed $12 \mathrm{~h}$ after the initiation of the hydration in the case of $\mathrm{P} 1$. As mentioned above, the activity of the quicklime contained in the CFBC ash was higher than that of reagent-grade quicklime. Fig. 7 shows the reaction ratio of anhydrous gypsum. The anhydrous gypsum contained in A CFBC ash showed a reaction ratio of about 57\% 30 minutes after the initiation of hydration; this ratio was much higher than that for $\mathrm{B}$ CFBC ash (10\%). This was because the active $\mathrm{Al}_{2} \mathrm{O}_{3}$ component produced ettringite. As shown in Table 4, the content of active $\mathrm{Al}_{2} \mathrm{O}_{3}$ component in $\mathrm{A}$ CFBC ash was $10.0 \%$, while no active $\mathrm{Al}_{2} \mathrm{O}_{3}$ component was detected in $\mathrm{B}$ CFBC ash.

With regard to the reaction ratio of anhydrous gypsum, the anhydrous gypsum contained in A CFBC ash rapidly reacted until 10 minutes after the initiation of the hydration; the reaction ratio gradually increased to reach $80 \%$ on day 91 of the material age. This indicates that the active $\mathrm{Al}_{2} \mathrm{O}_{3}$ component in A CFBC ash was first consumed to produce ettringite; then, the anhydrous gypsum was gradually converted to gypsum. The reaction ratio of anhydrous gypsum in B CFBC ash was about 10\% 10 minutes after the initiation of the hydration; the reaction of anhydrous gypsum continued until it was almost completed, on day 91 of the cured age. The reaction ratio of the natural anhydrous gypsum contained in $\mathrm{P} 1$ rapidly increased on day 7 of the mate- 


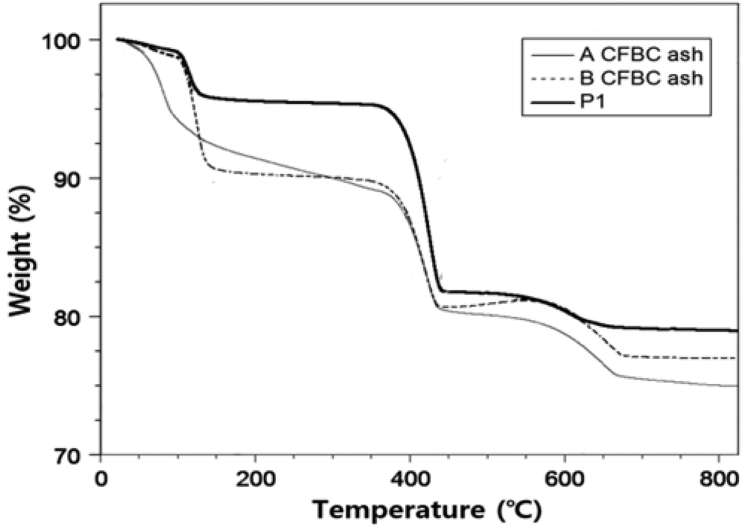

(a) TGA at the age of 28 days

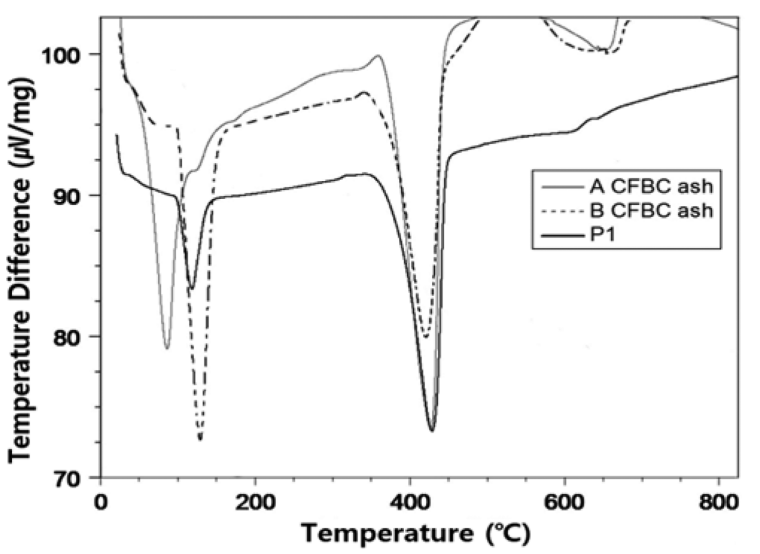

(b) DSC at the age of 28 days

Fig. 8. Thermal analysis of hydrated CFBC ash at 28 days (a) TGA, (b) DSC.

rial age, but after this the natural anhydrous gypsum was only slowly converted to gypsum. The anhydrous gypsum contained in the CFBC ash had a lower reactivity than that of natural anhydrous gypsum in alkaline atmosphere, but the reactivity was increased by the presence of active $\mathrm{Al}_{2} \mathrm{O}_{3}$.

Amorphous C-S-H hydrate was investigated by thermal analysis because it could not be investigated by XRD analysis. Fig. 8 shows the TG (a) and DSC (b) values on day 28 of the material age. A CFBC ash showed a drastic decrease of weight by about $6 \%$ between $40^{\circ} \mathrm{C}$ and $100^{\circ} \mathrm{C}$ (TG), and a big endothermic peak at $90^{\circ} \mathrm{C}$ (DSC). This result may be because of dehydration by ettringite. One ettringite molecule $\left(3 \mathrm{CaO} \cdot \mathrm{Al}_{2} \mathrm{O}_{3} \cdot 3 \mathrm{CaSO}_{4} \cdot 32 \mathrm{H}_{2} \mathrm{O}\right)$ includes 32 water molecules, 26 of which exist as weakly bound $\mathrm{H}_{2} \mathrm{O}$ molecules. Thus, dehydration starts at $40^{\circ} \mathrm{C}$ and continues until $200^{\circ} \mathrm{C}$. The remaining six $\mathrm{H}_{2} \mathrm{O}$ molecules, existing as $\mathrm{OH}$, are gradually dehydrated. ${ }^{12)}$ Therefore, the decrease of weight below $100^{\circ} \mathrm{C}$ is the result of dehydration by ettringite. The weight decrease from $100^{\circ} \mathrm{C}$ to $390^{\circ} \mathrm{C}$ can be as slow as $5 \%$. In this temperature interval, the weight decrease was due to the dehydration of gypsum, C-S-H, and ettringite. The small endothermic peaks at around $120^{\circ} \mathrm{C}$ (DSC) are considered to be the peaks representing the dehydration of gypsum. The rapid decrease of weight between $375^{\circ} \mathrm{C}$ and $440^{\circ} \mathrm{C}$ took place because of the dehydration of portlandite $\left(\mathrm{Ca}(\mathrm{OH})_{2}\right)$. In particular, the slow weight decrease (TG) between $100^{\circ} \mathrm{C}$ and $430^{\circ} \mathrm{C}$, found in the thermal analysis, has been reported to be the result of the dehydration of C-S-H. ${ }^{13,14)}$ The clay minerals contained in bituminous coal may be converted to amorphous metakaolin in the combustion process. ${ }^{13)}$ Hence, A CFBC ash may contain an active $\mathrm{SiO}_{2}$ component that may produce C-S-H. The method of measuring an active $\mathrm{SiO}_{2}$ component contained in a fly ash is provided in EN 197-2.9) As shown in Table 4, the content of active $\mathrm{SiO}_{2}$ component contained in A CFBC ash was $10.0 \%$ as measured by this method. In addition, A CFBC ash may facilitate the production of $\mathrm{C}-\mathrm{S}-\mathrm{H}$, because A CFBC ashA rapidly reaches a strong alkaline condition via the hydration of lime. ${ }^{15)}$ When $10 \mathrm{~g}$ of A CFBC ash was added to $100 \mathrm{ml}$ of water at room temperature and the mixture was stirred for $30 \mathrm{~min}$ utes, the $\mathrm{pH}$ was found to be 12.3. Therefore, A CFBC ash may produce C-S-H.

On the other hand, B CFBC ash showed a drastic weight decrease from $100^{\circ} \mathrm{C}$ to $150^{\circ} \mathrm{C}(8.0 \%)$ and a strong endothermic peak at $135^{\circ} \mathrm{C}$ that represented dehydration by gypsum. In addition, the rapid weight decrease and the strong endothermic peak from $375^{\circ} \mathrm{C}$ to $440^{\circ} \mathrm{C}(10.2 \%)$ were the results of the dehydration of portlandite, as in the case of A CFBC ash. A notable feature was that the weight did not decrease from $150^{\circ} \mathrm{C}$ to $375^{\circ} \mathrm{C}$, indicating that C-S-H was not produced. As can be seen in Table 4, the content of the active $\mathrm{SiO}_{2}$ component was too low (0.8\%) in B CFBC ash to produce C-S-H, and even if C-S-H was produced, the amount was presumed to be extremely small. In addition, heat generation and weight increase were found at around $550^{\circ} \mathrm{C}$ in the case of B CFBC ash. Further studies may need to be conducted to find out the causes of this phenomenon. P1 showed the same trend as that of B CFBC ash, although the weight decrease at each temperature interval was different; this sample showed only dehydration peaks and weight decrease due to gypsum and portlandite.

\subsection{Microstructural properties of hydrates}

Figure 9 shows the microstructure on day 1 of the hydration. In A CFBC ash, fibrous ettringite and various sizes of hexagonal-plate portlandite were found, and most hydrates were ettringite. In B CFBC ash, portlandite was observed on the anhydrous gypsum surface. The portlandite was extruded from the inside to the surface, which indicates that the quicklime inside the particles was extruded to the surface in the process of being converted to portlandite. In the case of $\mathrm{P} 1$, portlandite was the only hydrate found, and anhydrous gypsum had a smooth surface because hydration did not occur.

Figure 10 shows the microstructure on day 28 of the material age. In A CFBC ash, considerable amounts of ettringite and hexagonal-plate portlandite were found. C-S-H existed as tiny particles on a large particle. The presence of gypsum was verified by the XRD and thermal analysis, but no parti- 


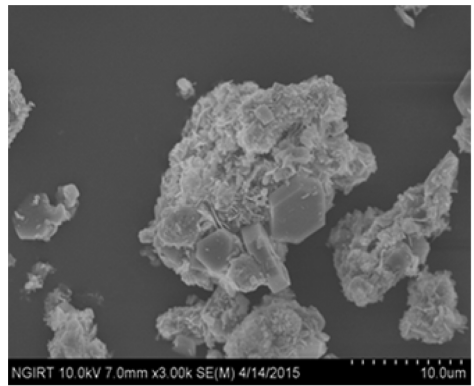

(a) A CFBC ash

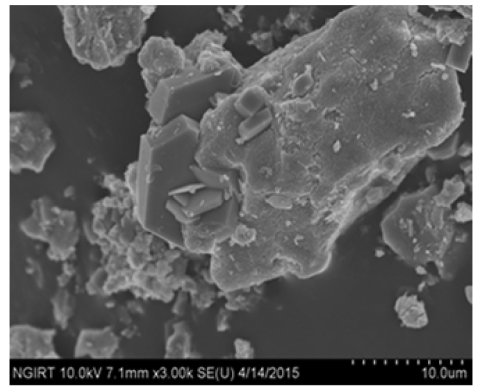

(b) B CFBC ash

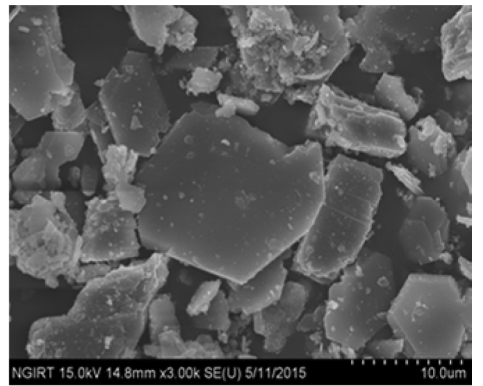

(c) P1

Fig. 9. SEM images of (a) A CFBC ash, (b) B CFBC ash, (c) P1 hydration at 1 days.

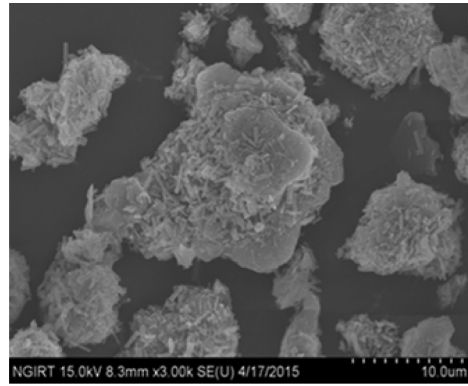

(a) A CFBC ash

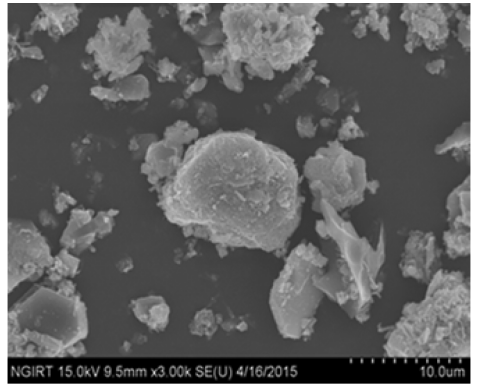

(b) B CFBC ash

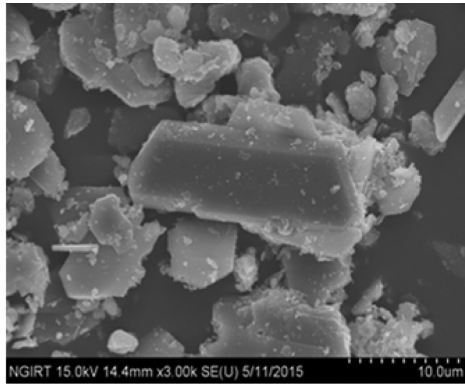

(c) P1

Fig. 10. SEM images of (a) A CFBC ash, (b) B CFBC ash, (c) P1 hydration at 28 days.

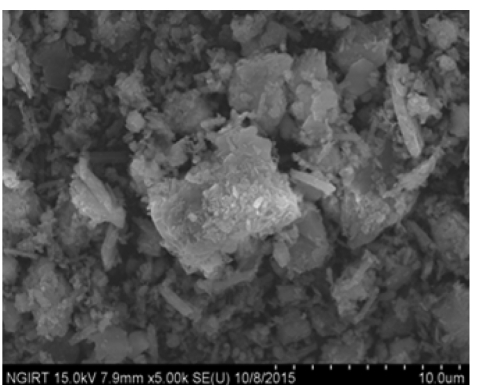

(a) A CFBC ash

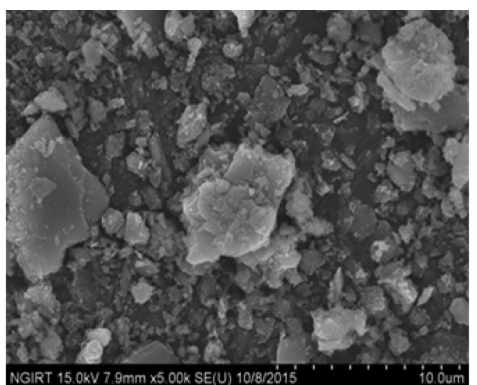

(b) B CFBC ash

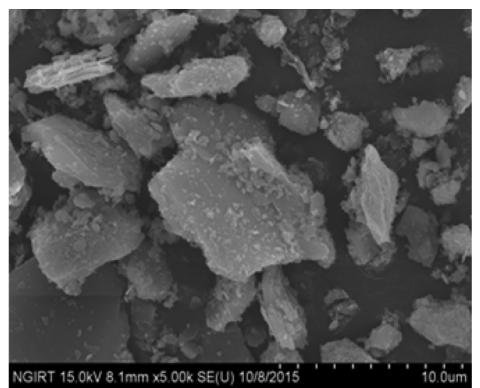

(c) P1

Fig. 11. SEM images of (a) A CFBC ash, (b) B CFBC ash, (c) P1 hydration at 91 days.

cles of gypsum were identified. The shape of gypsum converted from anhydrous gypsum has been reported to be similar to that of anhydrous gypsum, and thus the shape of gypsum could not be distinguished in the SEM images. ${ }^{16,17}$ ) $\mathrm{B}$ CFBC ash showed various sizes of portlandite, and the shape of the gypsum could not be distinguished, as in the case of A CFBC ash. The microstructure of P1 was similar to that of B CFBC ash, but portlandite and gypsum existed as independent particles due to the mixture of lime and anhydrous gypsum.

Figure 11 shows the microstructure on day 91 of the material age. The CFBC ash was hydrated to a considerable degree, as the reaction ratio of the anhydrous gypsum was more than $80 \%$. Therefore, A CFBC ash showed microstructures of portlandite, ettringite, gypsum, and C-S-H, while B CFBC ash showed a mixed microstructure of portlandite and gypsum. On the other hand, portlandite and gypsum, accounting for most of the hydrates of $\mathrm{P} 1$, were separated in the microstructure of $\mathrm{P} 1$.

\subsection{Review of hydration}

On the basis of the results described above, the hydration of CFBC ash may be evaluated as follows. The first reaction is the hydration of quicklime, in which portlandite is produced through the reaction shown in Equation (2). The second reaction involves anhydrous gypsum, portlandite, and active $\mathrm{Al}_{2} \mathrm{O}_{3}$ to produce ettringite through the reaction shown in Equation (3). After the production of ettringite, the remaining anhydrous gypsum is converted to gypsum by the reaction shown in Equation (4). However, since ettringite may not be produced in the absence of active $\mathrm{Al}_{2} \mathrm{O}_{3}$, the anhydrous gypsum in $\mathrm{B}$ CFBC ash is from the 


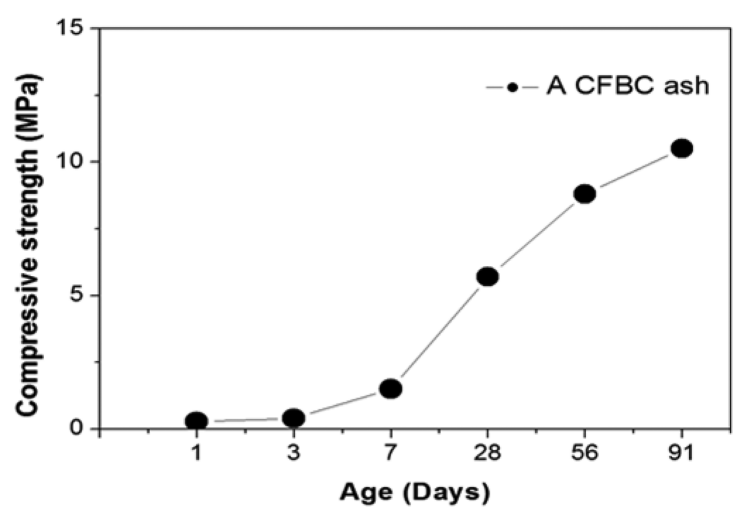

Fig. 12. Compressive strength of A CFBC ash paste.

beginning gradually converted to gypsum by the reaction shown in Equation (4). Therefore, the third reaction is the reaction of producing gypsum, wherein the product of the reaction is dependent on the presence of active $\mathrm{Al}_{2} \mathrm{O}_{3}$. The fourth reaction is expressed by Equation (5), where active $\mathrm{SiO}_{2}$ reacts with portlandite to produce C-S-H. B CFBC ash discharged from a boiler using petro coke as a fuel contains an extremely small amount of active $\mathrm{SiO}_{2}$ and thus is unable to produce C-S-H.

$$
\begin{aligned}
& \mathrm{CaO}+\mathrm{H}_{2} \mathrm{O} \rightarrow \mathrm{Ca}(\mathrm{OH})_{2} \\
& \quad 3 \mathrm{CaSO}_{4}+\mathrm{Ca}(\mathrm{OH})_{2}+\mathrm{Al}_{2} \mathrm{O}_{3}+31 \mathrm{H}_{2} \mathrm{O} \\
& \quad \rightarrow 3 \mathrm{CaO} \cdot \mathrm{Al}_{2} \mathrm{O}_{3} \cdot 3 \mathrm{CaSO}_{4} \cdot 32 \mathrm{H}_{2} \mathrm{O} \\
& \mathrm{CaSO}_{4}+2 \mathrm{H}_{2} \mathrm{O} \rightarrow \mathrm{CaSO}_{4} \cdot 2 \mathrm{H}_{2} \mathrm{O} \\
& \mathrm{SiO}_{2}+\mathrm{xCa}(\mathrm{OH})_{2}+(\mathrm{y}-\mathrm{x}) \mathrm{H}_{2} \mathrm{O} \rightarrow \mathrm{CxSHy}(\mathrm{C}-\mathrm{S}-\mathrm{H})
\end{aligned}
$$

Figure 12 shows the compressive strength of the CFBC ash paste. B CFBC ash discharged from a boiler using petro coke as a fuel produced portlandite and gypsum as hydrates, but the compressive strength could not be measured because the strength was too low. On the contrary, A CFBC ash produced ettringite and C-S-H as hydrates, and the measured compressive strength was $5.7 \mathrm{MPa}$ on day 28 of the material age and $10.5 \mathrm{MPa}$ on day 91 of the hydration. This result shows that the CFBC ash from a boiler using bituminous coal as a fuel had higher strength.

\section{Conclusions}

In the present study, the self-cementitious property of CFBC fly ashes discharged from boilers using bituminous coal and petro coke as fuels was investigated, with the following conclusions.

1) B CFBC ash discharged from a boiler using petro coke as a fuel includes about four times more $\mathrm{SO}_{3}$ and about $6.2 \%$ more $\mathrm{CaO}$, but about $15.6 \%$ less $\mathrm{SiO}_{2}$ and $\mathrm{Al}_{2} \mathrm{O}_{3}$ than $\mathrm{A}$ CFBC ash discharged from a boiler using bituminous coal as a fuel. Therefore, the hydration reactivity of the CFBC fly ashes was found to be dependent on the fuels used and to differences in the chemical composition.
2) The shape of the CFBC fly ash particles was irregular, regardless of the fuels used, in contrast to the particle shape of the pulverized coal combustion boiler fly ash. The inside of the particles was composed of quicklime, but the surface had an anhydrous gypsum layer. The quicklime underwent a rapid hydration reaction immediately after supplying water to mainly produce portlandite with a reaction ratio of about $95 \% 30$ minutes after the initiation of the hydration.

3) The hydration of anhydrous gypsum contained in the CFBC ash was affected by $\mathrm{Al}_{2} \mathrm{O}_{3}$ : the reaction ratio of $\mathrm{A}$ CFBC ash containing $5.8 \%$ of $\mathrm{Al}_{2} \mathrm{O}_{3}$ was about $57 \% 30$ minutes after the initiation of the hydration, while that of $\mathrm{B}$ CFBC ash containing $0.5 \%$ of $\mathrm{Al}_{2} \mathrm{O}_{3}$ was about $10 \%$. The product from the anhydrous gypsum contained in A CFBC ash was initially ettringite, and then gypsum after the active $\mathrm{Al}_{2} \mathrm{O}_{3}$ had been completely consumed. On the other hand, only gypsum was produced in the case of $\mathrm{B}$ CFBC ash containing little $\mathrm{Al}_{2} \mathrm{O}_{3}$.

4) A C-S-H hydrate was produced from A CFBC ash containing $10.0 \%$ active $\mathrm{SiO}_{2}$, but not from $\mathrm{B}$ CFBC ash containing only $0.8 \%$ of active $\mathrm{SiO}_{2}$. Therefore, the compressive strength of $\mathrm{B}$ CFBC ash discharged from a boiler using petro coke as a fuel could not be measured because the strength was too low; however the compressive strength of A CFBC ash, which produced C-S-H and ettringite as hydrates, was found to be $5.7 \mathrm{MPa}$ on day 28 of the material age.

\section{Acknowledgments}

This research was supported by a grant (16SCIP-B10370602) from the Construction Technology Research Program funded by the Ministry of Land, Infrastructure and Transport of the Korean Government.

\section{REFERENCES}

1. F. H. Li, J. P. Zhai, X. R. Fu, and G. H. Sheng, "Characterization of Fly Ashes from Circulating Fluidized Bed Combustion (CFBC) Boilers Cofiring Coal and Petroleum Coke," Energy Fuels, 20 [4] 1411-17 (2006).

2. Y. H. Wu, E. J. Anthony, and L. F. Jia, "Steam Hydration of CFBC Ash and the Effect of Hydration Conditions on Reactivation," Fuel, 83 [10] 1357-70 (2003).

3. G. H. Sheng, Q. Li, and J. P. Zhai, "Investigation on the Hydration of CFBC Fly Ash," Fuel, 98 61-6 (2012).

4. J. F. Georgin and E. Prud'homme, "Hydration Modelling of an Ettringite-Based Binder," Cem. Concr. Res., 76 51-61 (2015).

5. M. Cheriaf, J. C. Rocha, and J. Péra, "Pozzolanic Properties of Pulverized Coal Combustion Bottom Ash," Cem. Concr. Res., 29 1387-91 (1999).

6. E. Raask and M. C. Bhaskar, "Pozzolanic Activity of Pulverized Fuel Ash," Cem. Concr. Res., 5 363-75 (1975).

7. C. Freidin, "Influence of Variability of Oil Shale Fly Ash on Compressive Strength of Cementless Building Compounds," Constr. Build. Mater., 19 [2] 127-33 (2005). 
8. G. H. Sheng, J. P. Zhai, Q. Li, and F. H. Li, "Utilization of Fly Ash Coming from a CFBC Boiler Cofiring Coal and Petroleum Coke in Portland Cement," Fuel, 86 [16] 2625-31 (2007).

9. EN 196-2, "Methods of Testing Cement - Part 2: Chemical Analysis of Cement," European Committee for Standardization, 2005.

10. KS L 5405, "Fly Ash," Korean Industrial Standards, 2016.

11. E. J. Anthony, L. Jia, and Y. Wu, "CFBC Ash Hydration Studies," Fuel, 84 [11] 1393-97 (2005).

12. Gruskovnjak, B. Lothenbach, F. Winnefeld, R. Figi, S. C. Ko, M. Adler, and U. Mäder, "Hydration Mechanisms of Super Sulphated Slag Cement," Cem. Concr. Res., 38 [7] 983-92 (2008).

13. M. E. Kalinski and P. K. Yerra, "Hydraulic Conductivity of
Compacted Cement-Stabilized Fly Ash," Fuel, 85 [16] 233036 (2006).

14. N. T. Dung, T. P. Chang, and C. H. Chen, "Engineering and Sulfate Resistance Properties of Slag-CFBC Fly Ash Paste and Mortar," Constr. Build. Mater., 63 40-8 (2014).

15. G. H. Sheng, Q. Li, J. P. Zhai, and F. H. Li, "Self-Cementitious Properties of Fly Ashes from CFBC Boilers Co-Firing Coal and High-Sulphur Petroleum Coke," Cem. Concr. Res., 37 [6] 871-76 (2007).

16. T. Sievert, A. Wolter, and N. S. Singh, "Hydration of Anhydrite of Gypsum $\left(\mathrm{CaSO}_{4}\right.$.II) in a Ball Mill," Cem. Concr. Res., 35 [4] 623-30 (2005).

17. Y. Shen, J. Quin, and Z. Zhang, "Investigation of Anhydrite in CFBC Fly Ash as Cement Retarders," Constr. Build. Mater., 40 672-78 (2013). 